\title{
A review of the genus Ditylometopa Kertész (Diptera: Stratiomyidae)
}

\author{
NORMAN E. WOODLEY \\ Systematic Entomology Laboratory, PSI, ARS, USDA, \% Smithsonian Institution NHB-168, P O Box 37012, Washington, DC 20013- \\ 7012,USA.E-mail: norman.woodley@ars.usda.gov
}

\begin{abstract}
The genus Ditylometopa Kertész (Diptera: Stratiomyidae, Clitellariinae), which occurs only in the Neotropical Region, is reviewed. Euryneura rufifrons Curran, 1934 is synonymized with Ditylometopa elegans Kertész, 1923. A neotype is designated for D. elegans. Two species are recognized, including Ditylometopa centralensis sp. nov., which is described from Costa Rica (type locality) and Nicaragua and may occur in Brazil.
\end{abstract}

Key words: Ditylometopa elegans, D. centralensis, new species, Stratiomyidae, Neotropical, taxonomy

\section{Introduction}

Little is known about Ditylometopa Kertész, a genus of soldier flies (Stratiomyidae) in the subfamily Clitellariinae. Two species have been recognized previously (Woodley 2001), but specimens have remained rare in collections and males of the recognized taxa have not been described. Some relatively recent, intensive collecting by Malaise trapping and canopy fogging has resulted in the availability of some additional specimens, including males. The examination of male genitalia allowed for the re-evaluation of species limits in the genus.

Ditylometopa is related to the genera Euryneura Schiner, Diaphorostylus Kertész, Meringostylus Kertész, and Quichuamyia Brammer. Brammer \& von Dohlen (2007), in a molecular phylogenetic study aimed at resolving the major lineages of stratiomyids, concentrating on the subfamily Clitellariinae, found that Euryneura, Diaphorostylus, and Ditylometopa formed a lineage they called the Euryneura clade. This supported Kertész's $(1908,1923)$ idea that these genera were related based on their generally similar appearance.

\section{Material and methods}

Morphological terminology follows McAlpine (1981). Specimens examined in this study are from the American Museum of Natural History, New York, New York (AMNH); California Department of Food and Agriculture, Sacramento, California (CDFA); Instituto Nacional de Biodiversidad, Santo Domingo, Costa Rica (INBio); and the National Museum of Natural History, Smithsonian Institution, Washington, D.C. (USNM).

\section{Genus Ditylometopa Kertész}

Ditylometopa Kertész, 1923: 114. Type species, Ditylometopa elegans Kertész, by original designation. 
Diagnosis. Ditylometopa can be separated from other Neotropical clitellariines by its front femur which has a carinate, triangular process on the ventral surface (Fig. 7). In fact, no other stratiomyid that I am aware of has such a feature, so it seems clear that this character state is autapomorphic for the genus. Females of Ditylometopa have the medial region of the upper frons bulging, with a narrow median carina. This character state is also autapomorphic for Ditylometopa. Other character states exhibited by Ditylometopa are briefly summarized:

Medium-sized soldier flies, 5.6-6.9 mm in length. Male. Head (Figs. 1, 2) strongly holoptic on upper frons, eyes large, dorsal ommatidia enlarged. Antennae shorter than head, flagellum slightly spindle-shaped, the first six flagellomeres subequal in size, seventh and eighth narrower and slightly offset in the form of a short style, eighth bluntly to sharply conical. Oral cavity with posterior margin produced, rounded. Palpus small, two-segmented, partly hidden by oral margin. Thorax with scutellum trapezoidal, disc evenly convex, with two marginal spines that are less than half the length of the scutellum. Wing evenly set with microtrichia but alula mostly bare; $R_{2+3}$ arising distal to $r-m$ by about its length; $R_{4}$ present; $M_{1}, M_{2}, M_{3}$, and $C u A_{1}$ all arising from discal cell, equally well developed, $\mathrm{M}_{1}, \mathrm{M}_{2}$, and $\mathrm{CuA}_{1}$ reaching wing margin, $\mathrm{M}_{3}$ ending just before wing margin. Abdomen nearly round in dorsal view, about as long as wide.

Female. Differs from male as follows: Eyes smaller (Figs. 3, 4), widely separated by upper frons, ommatidia uniform in size. Palpus slightly larger than in male.

Remarks. Specimens of Ditylometopa are rarely collected, and nothing is known about the biology of the genus. Most specimens have been taken by mass trapping methods in low elevation tropical forests. The only specimen I have personally collected was sitting on a leaf along a forest trail.

\section{Key to species of Ditylometopa Kertész}

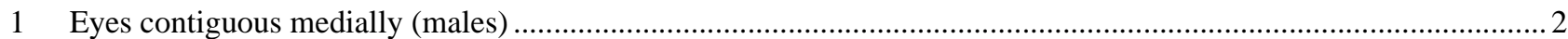

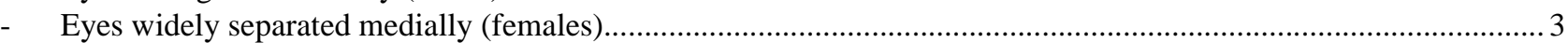

2 Fifth abdominal tergite with a pair of moderately well defined pubescent spots (as in Fig. 5); eighth flagellomere bluntly pointed apically.

D. elegans Kertész

- $\quad$ Fifth abdominal tergite with pubescence less dense, not forming well defined spots (as in Fig. 6); eighth flagellomere sharply pointed apically ..... D. centralensis sp. nov.

3 Lower frons with isolated medial spot of tomentum immediately above antennae, surrounding area bare and shiny, especially along upper margin of lower frons; scutellar spines larger, separated by two times the length of a spine or less; anterolateral areas of fifth tergite with pale hairs, this pale vestiture more diffuse, not forming distinct bands (Fig. 6); occurring in Central America, ?Brazil. D. centralensis sp. nov.

- Lower frons with more diffuse areas of tomentum above antennae, resulting in less conspicuous shiny areas, upper margin of lower frons mostly thinly tomentose; scutellar spines shorter, separated by greater than two times the length of a spine; anterolateral areas of fifth tergite with inconspicuous dark vestiture, the areas of pale vestiture forming distinct bands that widen posteriorly (Fig. 5); occuring in South America . D. elegans Kertész

\section{Ditylometopa elegans Kertész}

(Figs. 1, 3, 5, 7-11)

Ditylometopa elegans Kertész, 1923: 115.

Euryneura rufifrons Curran, 1934: 314. New Synonymy.

Diagnosis. Both males and females of this species have a pair of well defined band-like pubescent markings on the fifth tergite (Fig. 5). Males of D. elegans have the eighth antennal flagellomere slightly larger and more blunt apically than that of $D$. centralensis, and the posterior margin of the hypandrium is evenly rounded (Fig. 8), rather than slightly bilobed as in $D$. centralensis. Females have the surface of the lower frons above the antennae more extensively tomentose than in D. centralensis, lacking well defined shiny areas; the margins of 
the lower frons and face have a wider strip of tomentum than in D. centralensis; and the sutural area between the vertex and post-ocular orbits is usually darkened, with a deep groove just mediad of the suture.
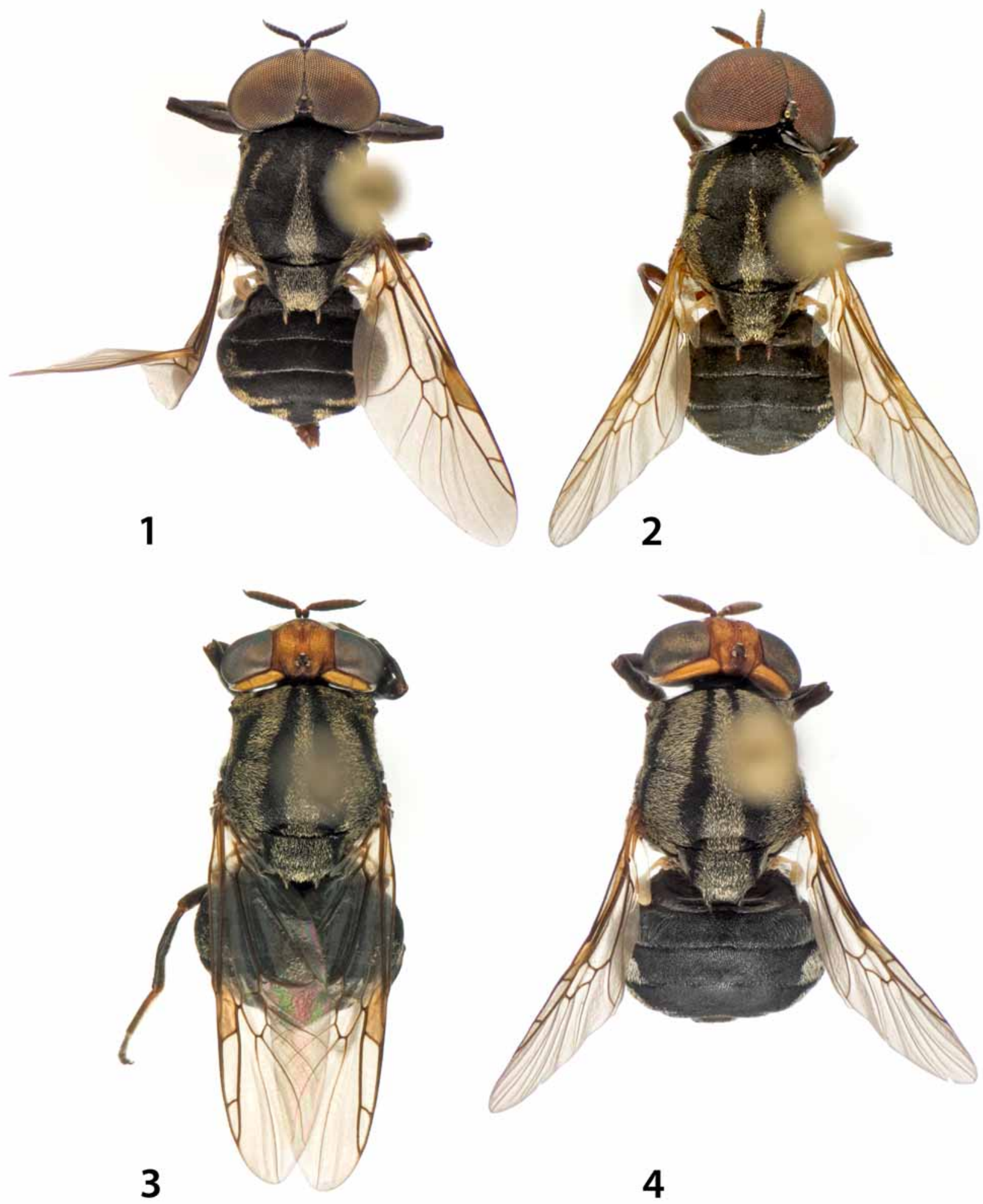

FIGURES 1-4. Habitus images of Ditylometopa species. 1, D. elegans, male. 2, D. centralensis, male. 3, D. elegans, female. 4 , D. centralensis, female.

Description. Male. Head black, ocellar tubercle usually brownish. Lower frons and face with extremely narrow tomentose margins, extending around lower eye margin and lower half of posterior eye margin; lower frons and face with sparse tomentum medially, ocellar tubercle with traces of fine tomentum. Silvery white 
pilosity present on lateral portions of lower frons and most of face that is less than length of scape and somewhat recumbent; similar hair-like setae present on gena and lower occiput but pilosity is more erect. Eyes bare. Antennae brownish, darker on outer surface; eighth flagellomere bluntly conical at apex; scape and pedicel with short, sparse black hair-like setae, especially apically, on each segment; pedicel with short, sparse pale hair-like setae on medial surface. Proboscis and palpus brownish-black, lower part of labellum dirty yellowish-white.

Thorax black, pleural sclerites just below wing base and tiny areas on postpronotal lobe and postalar callus brownish, scutellar spines yellowish. Scutum and scutellum finely granulate, not shiny; with vestiture of short, appressed black hair-like setae except on areas where longer pale golden pilosity forms a pattern (Fig. 1): a quadrate spot on the presutural notopleural region; a sublateral vitta that narrows anteriorly, extending from the postalar wall anteriorly to beyond suture; and a median vitta that covers most of the disc of scutellum and narrows anteriorly to beyond suture. Pleurites with vestiture composed of mostly short, appressed silvery hair-like setae over most of surface, bare areas present on central part of anepisternum and posterior part of anepimeron; central part of anepisternum with noticeable vertical striations. Legs completely dark brownish to black, mid and hind legs with first tarsomeres indistinctly brownish to dark yellow. Wing faintly, evenly infuscated with grayish color, cell $\mathrm{r}_{1}$ ("stigma") dark yellowish; wing blade uniformly set with microtrichia, with most of alula and small area of anal lobe near incision bare. Halter dark, dull yellowish in color.

Abdomen black, sternites more brownish, tergites with surfaces finely granulate as on scutum. Central portions of tergites with very short, inconspicuous, appressed black hair-like setae; tergites 1 and 2 with longer, mostly dark hair-like setae laterally; tergites 3 and 4 with well-defined lateral spots of golden pilosity with the posterior margin of each extending medially along suture for a short distance; tergite 5 with lateral, band-like golden markings, each expanded along posterior margin (Fig. 5). Sternites with more or less uniform vestiture of short, appressed silvery hair-like setae; sternite 1 with some longer, erect hair-like setae medially.

Male terminalia with gonocoxites (Fig. 8) nearly parallel-sided but tapering slightly anteriorly; posterior margin of hypandrium very slightly produced and rounded, ventrally with carina-like ridge; gonostylus simple, slightly narrowed toward apex and with outer margin arcuate; gonocoxal apodemes elongate, extending beyond anterior margin of genital capsule; phallic complex (Figs. 9, 11) slender, trifid, the lobes apparently fused anteriorly, medial lobe very slightly shorter than lateral lobes, attachment structure small; epandrium (Fig. 10) nearly quadrate, longer than wide, posterior margin truncate.

Body length, 5.7-6.1 mm.

Female. Differs from male as follows: Head (Fig. 3) black, with wide frons as noted in generic description; upper frons, narrow lateral margins of lower frons and face and occiput along posterior and ventral margin of eye orangish-yellow. Upper frons $0.36-0.40$ width of head, rugose, inflated, slightly depressed along medial line where there is a sharp, narrow, medial carina; vertex with narrow, deep depression on each side just mediad of upper corner of eye, this area darker than surrounding surface. Upper frons with scattered, recumbent black pilosity except on lower medial part where the hair-like setae are silvery; lateral margins of lower frons and much of face with short, silvery pilosity, especially dense medially on the latter. Lower frons with scattered thin tomentum, without conspicuous shiny areas; dense tomentum present on lateral margins of lower frons and face which continues ventrally along eye margin and along about lower two thirds of posterior margin of eye, wider and more conspicuous than in male. Palpus slightly larger than in male.

Thorax with scutellar spines shorter than in male, sometimes partly blackish. Golden pubescent pattern on scutum more extensive (Fig. 3), with the medial and sublateral vittae extending to anterior margin, and the notopleural pilosity more extensive, extending over postpronotal lobe and coalescing with anterior portion of sublateral vitta.

Abdomen essentially as in male; cercus small, slender, first segment about twice length of second.

Body length, 5.6-6.7 mm. 

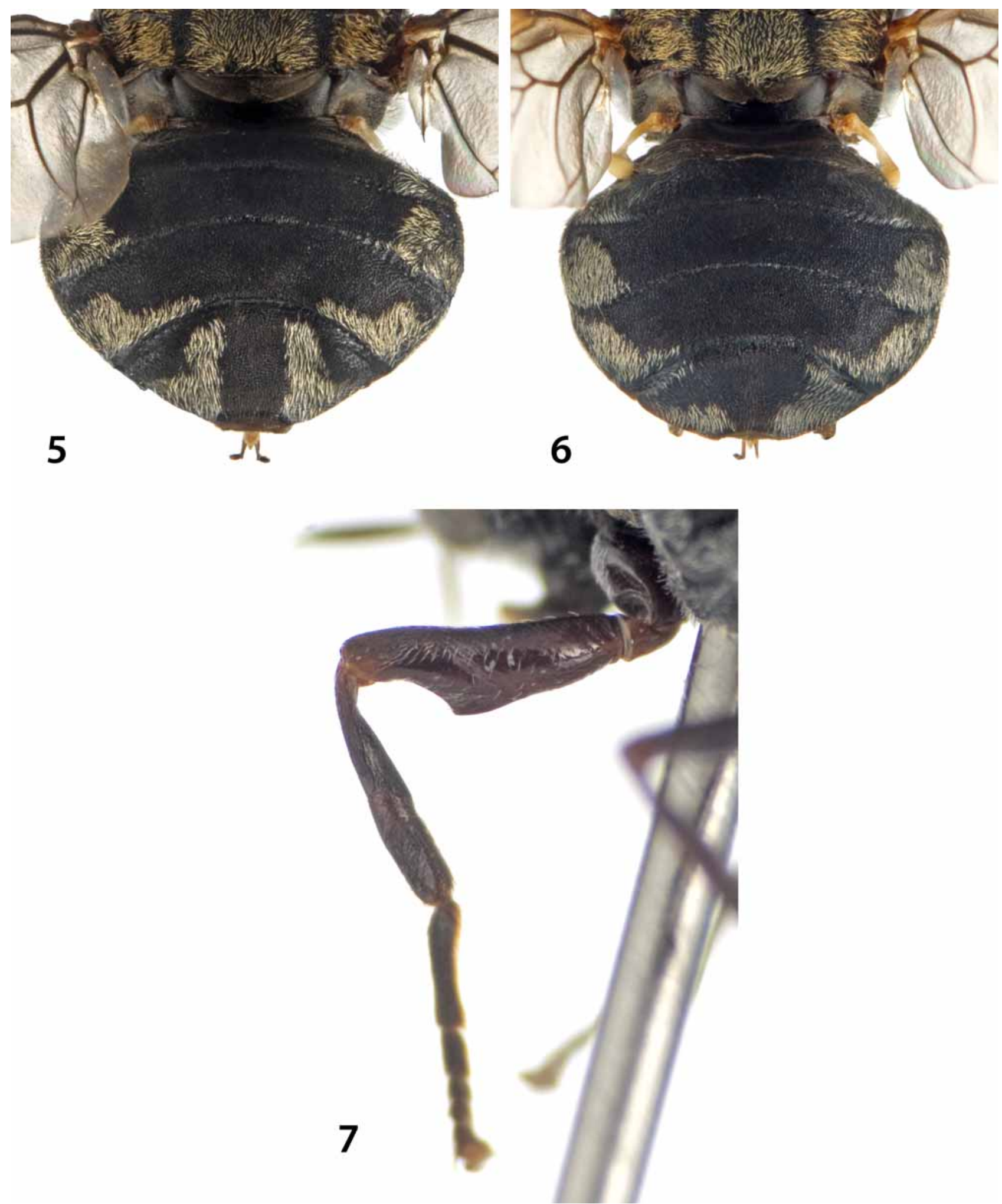

FIGURES 5-7. Morphological details of Ditylometopa species. 5, D. elegans, dorsal view of female abdomen. 6, D. centralensis, dorsal view of female abdomen; note: this image makes the abdominal hairs appear denser than they actually are. 7, D. elegans, posterior view of front femur of male.

Specimens examined. Type material: Ditylometopa elegans Kertész. Kertész described his species based on two female syntypes, one from Vilcanota, Peru and one from Espírito Santo, Brazil. Both were subsequently destroyed at the Hungarian Natural History Museum, Budapest in the 1956 uprising. In the interest of nomenclatural stability, and because the known species of Ditylometopa are very similar, I am 
hereby designating the female holotype of Euryneura rufifrons Curran as the neotype of Ditylometopa elegans Kertész, which results in their permanent synonymy. The detailed label data for this specimen is presented below.

Euryneura rufifrons Curran. The female holotype, housed at AMNH, is labeled (slashes separate individual labels): "24726/Kartabo Bartica District British Guiana 1924/Euryneura ? TYPE rufifrons $q$ Curran No./Euryneura ? rufifrons Curran Det. C.H. Curran/NEOTYPE $q$ Ditylometopa elegans Kertész, 1923 des. N. E. Woodley 2008". The specimen is in excellent condition. Although Curran (1934: 314) stated that the specimen was collected May 26, 1924, this is not indicated on the labels (unless the first typewritten label on the specimen is the date, in which case it is incorrectly cited and should be July 26, 1924).

Other material. 1 , BOLIVIA: Santa Cruz Department, Ichilo Province, Hotel Flora y Fauna, 4-6 km SSE Buena Vista, $17^{\circ} 29.95^{\prime} \mathrm{S}, 63^{\circ} 33.15^{\prime} \mathrm{W}, 400-500 \mathrm{~m}, 12$ November 2003, N.E. Woodley (USNM); 19 , BRAZIL: Para, Tapajos, Boa Vista, 23 February, C.H.T. Townsend (USNM); 2 , BRAZIL: Rondania, Fazenda Rancho Grande, $62 \mathrm{~km} \mathrm{~S}$. Ariquemes, $10.32^{\circ} \mathrm{S}, 62.48^{\circ} \mathrm{W}, 165 \mathrm{~m}, 12-22$ November 1991, E. M. Fisher (CDFA, USNM); 1 , ECUADOR: Napo, Reserva Ethnica Waorani, $1 \mathrm{~km}$ S Onkone Gare Camp, $00^{\circ} 39^{\prime} 10^{\prime \prime} \mathrm{S}, 76^{\circ} 26^{\prime} \mathrm{W}, 220 \mathrm{~m}, 9$ October 1994, T.L. Erwin et al., insecticidal fogging of mostly bare green leaves, some with covering of lichenous or bryophytic plants in terre firme forest, Lot 912 (USNM); $1 \jmath^{\lambda}$, same data but 8 February 1995, Lot 962 (USNM); 1ð, same data but 10 February 1995, Lot 1008 (USNM); 10 , same data but 4 February 1996, Lot 1414 (USNM); 2 (paratypes of E. rufifrons), GUYANA (as British Guiana): Bartica District, Kartabo, 23 May 1924 (AMNH); 1 ( (paratype of E. rufifrons), same data but 11 June 1924 (AMNH); 1 \% , VENEZUELA: Mt. Duida, 18 November 1928 (AMNH); 1 , VENEZUELA: T.F. Amazonas, Cerro de la Neblina basecamp, $0^{\circ} 50^{\prime} \mathrm{N}, 66^{\circ} 10^{\prime} \mathrm{W}, 140 \mathrm{~m}, 27$ January 1985, P.J. \& P.M. Spangler, R.A. Faitoute, W.E. Steiner (USNM).

Remarks. Even though the type material of Kertész (1923) has been destroyed, it is clear from his excellent description that he was describing a species of Ditylometopa with well-defined golden pubescent spots on the fifth abdominal tergite. However, there is a good possibility that his second specimen from Espírito Santo, Brazil was a species different from D. elegans that has not otherwise been recorded from the Atlantic coast of Brazil. Also, there is a questionable specimen of $D$. centralensis known from southern Brazil (noted below under that species). That specimen has a distinct dark spot on the knob of the halter, and Kertész (1923: 116) noted that the Espírito Santo specimen had this feature as well. For this reason, I believe that it is best to designate a neotype for Kertész's taxon to stabilize the species concepts in the genus.

Specimens of Ditylometopa are rare in collections. The only males of D. elegans I have seen were collected by canopy fogging, so it is possible that species of the genus are normally denizens of the canopy and only occasionally occur at lower forest levels and hence are not often collected.

\section{Ditylometopa centralensis sp. nov.}

(Figs. 2, 4, 6, 12-15)

Diagnosis. Both males and females of this species lack well defined band-like pubescent markings on the fifth tergite as found in D. elegans, but have inconspicuous, more diffuse pubescence on the lateral third of the tergite (Fig. 6). Males of D. centralensis have the eighth antennal flagellomere slightly smaller and more pointed apically than that in D. elegans, and the posterior margin of the hypandrium is slightly bilobed (Fig. 12) rather than evenly rounded as in $D$. centralensis. Females have the surface of the lower frons above the antennae less tomentose than in D. elegans, with well defined shiny areas; the margins of the lower frons and face have a narrower strip of tomentum than in D. elegans; and the sutural area between the vertex and postocular orbits is usually not darkened, with a shallower groove just mediad of the suture.

Description. Ditylometopa centralensis is very similar to D. elegans, but differs from it as follows: Male. Head with lower frontal triangle less tomentose, lateral areas somewhat shiny. Antenna with scape and pedicel dark brownish-yellow; eighth flagellomere sharply conical at apex. 

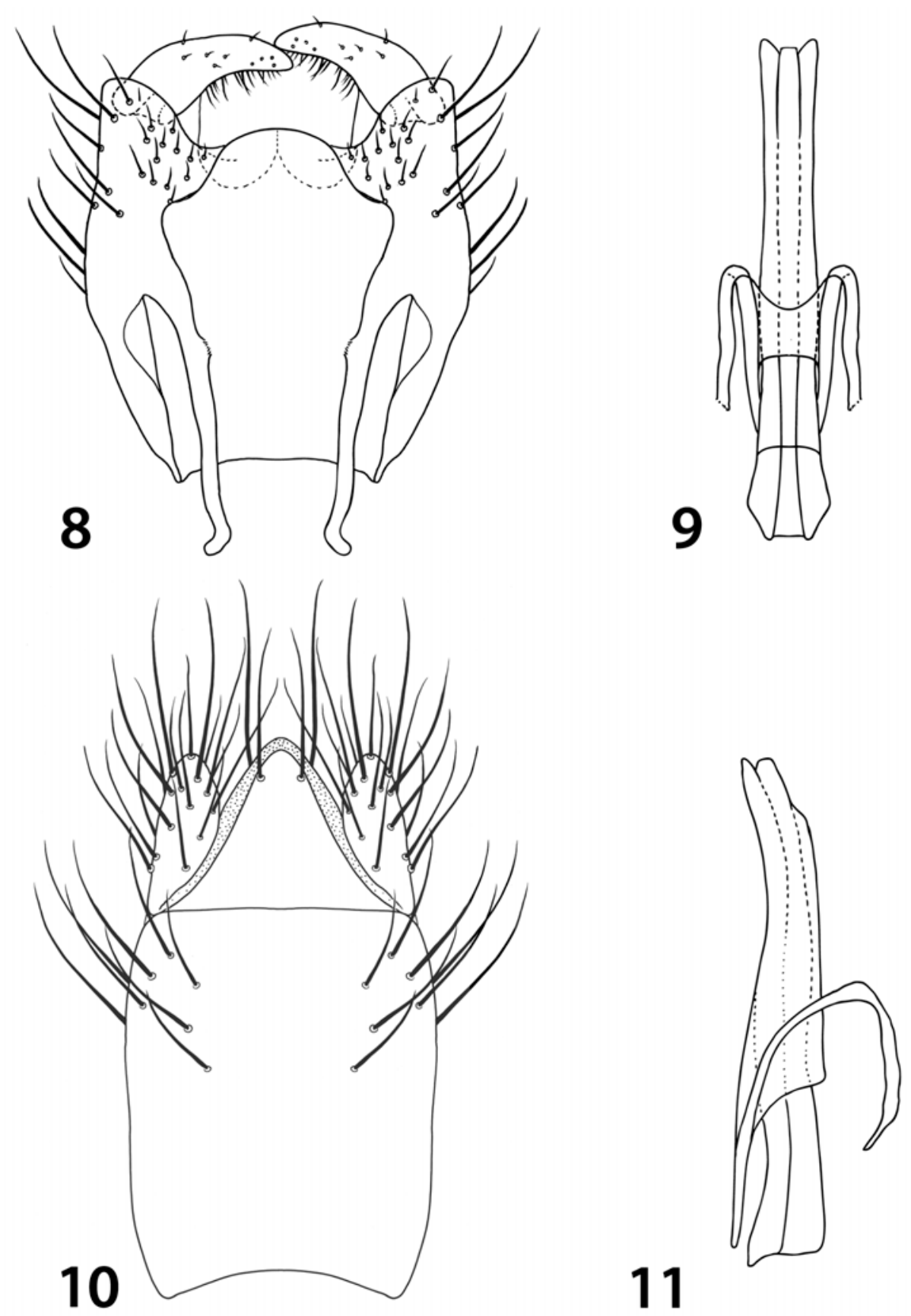

FIGURES 8-11. Male terminalia of Ditylometopa elegans. 8, genital capsule, dorsal view. 9, phallic complex, dorsal view. 10, epandrium and post-genital segments, dorsal view. 11, phallic complex, left lateral view.

Thorax with scutellar spines black, becoming vaguely paler on apical halves. Pale vestiture of scutum slightly more silvery than in D. elegans but with same basic pattern (Fig. 2). Wing slightly more yellowish, with cell $r_{1}$ ("stigma") not as strongly contrasting with rest of wing (Fig. 2).

Abdomen with pale vestiture on tergites sparser and more silvery than in D. elegans, not forming as distinct a pattern as in that species; lateral pubescent spots on tergites 3 and 4 narrower; tergite 5 with lateral thirds with more diffuse pale pubescence not forming well demarcated spots (Fig. 6).

Male terminalia with gonocoxites similar to those of D. elegans (Fig.12); posterior margin of hypandrium slightly produced, distinctly bilobed medially; phallic complex (Figs. 13, 15) slightly more robust than in $D$. elegans, medial lobe very slightly longer than lateral lobes; epandrium (Fig. 14) not as quadrate, more ovoid, posterior margin rounded at lateral corners.

Body length, $6.1 \mathrm{~mm}$. 

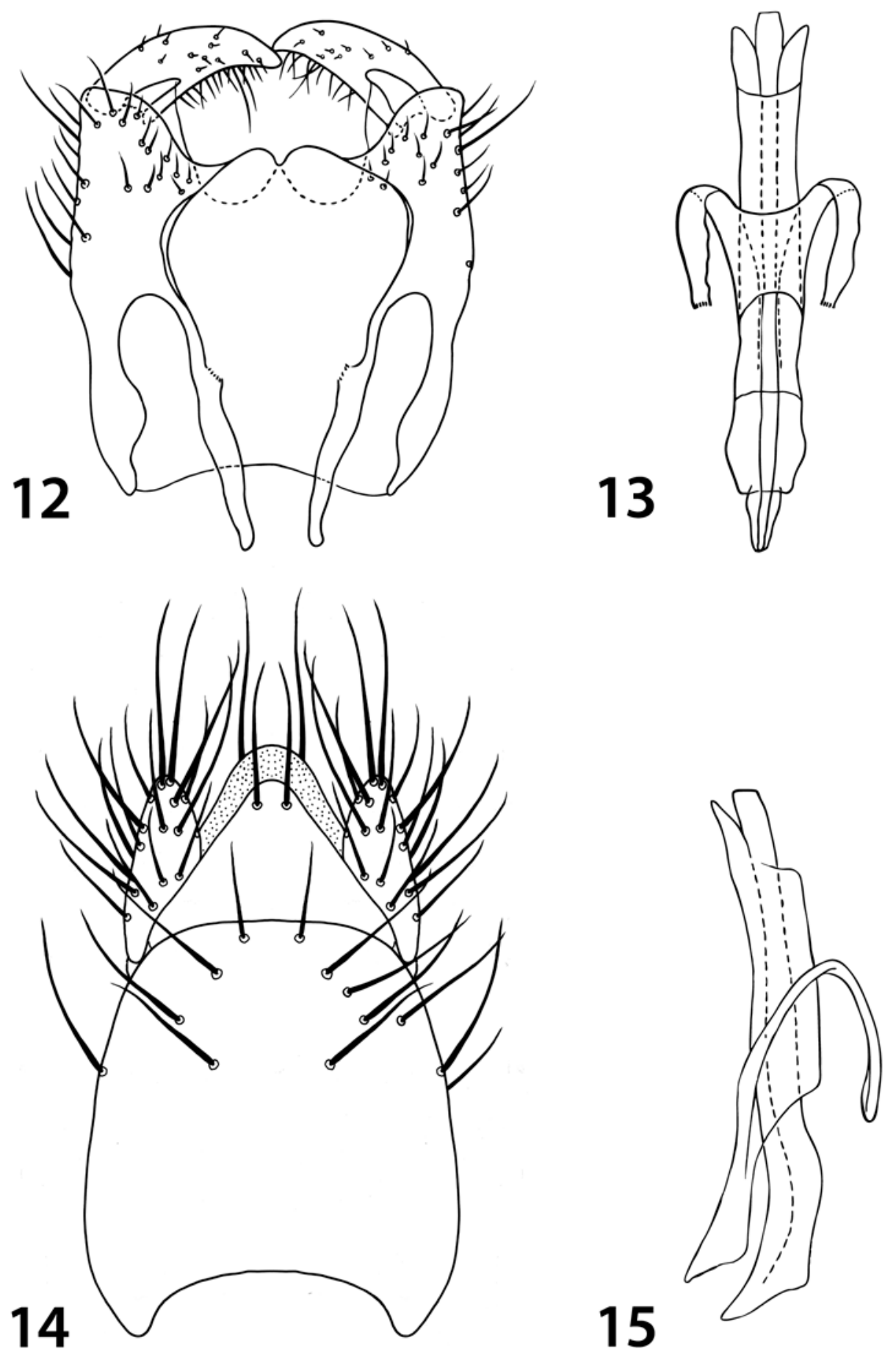

FIGURES 12-15. Male terminalia of Ditylometopa centralensis. 12, genital capsule, dorsal view. 13, phallic complex, dorsal view. 14, epandrium and post-genital segments, dorsal view. 15, phallic complex, left lateral view.

Female. Head with frons $0.33-0.36$ of head width at anterior ocellus; vertex with narrow, shallow depression on each side just mediad of upper corner of eye, this area not darkened. Lower frons with only a small medial tomentose area just above antennae, rest of surface appearing shiny with scattered hairs. Dense tomentum present on lateral margins of lower frons and face but narrower than in D. elegans.

Thorax with scutellar spines slightly shorter than in male, occasionally more yellowish. Pale pilosity of scutum slightly more silvery than that of D. elegans; notopleural pilosity not coalescing as strongly with anterior portion of sublateral vitta, thus the vitta is more discrete anteriorly (Fig. 4). Halter with knob occasionally darkened near base laterally. 
Abdomen essentially as in male, with less strongly demarcated pubescent spots than in D. elegans, especially on tergite 5 .

Body length, 5.9-6.9 mm.

Specimens examined. Holotype ${ }^{\lambda}$, COSTA RICA: Guanacaste Province, Estación Murciélago, 8 km SW of Cuajiniquil, 100m, L N 320300_347200, 22 July 1993, C. Cano (INBio). The holotype is in excellent condition. Paratypes: 1 , , same data as holotype but 6-23 June 1994, F.A. Quesada (INBio); 1 , , COSTA RICA: Guanacaste Province, Tilarán, Tierras Morenas, 685 m, L N 287800_427600, July 1994, G. Rodríguez (INBio; missing head and right wing); 1 , COSTA RICA: Puntarenas Province, $3 \mathrm{~km} \mathrm{SW}$ of Rincon, $10 \mathrm{~m}$, $8^{\circ} 41^{\prime} \mathrm{N}, 8^{\circ} 29^{\prime} \mathrm{W}$, March-May 1991, P. Hanson, Malaise trap (USNM); 1 q, NICARAGUA: Leon, June 1990, B. Garete (USNM).

Additional material, not paratype: 1へ, BRAZIL: Santa Catarina, Corupa (Hansa Humboldt), November 1944, A. Maller (AMNH).

Etymology. The species epithet refers to the primary range of this species, Central America.

Remarks. The male examined from Brazil is quite similar to the holotype male from Costa Rica, but differs in some minor respects. The knob of the halter of the Brazilian male is darkened laterally on the basal half (not darkened in the holotype), and all basal tarsomeres are blackish (dark yellowish on mid and hind tarsi in the holotype). In the male genitalia, the lateral lobes of the phallic complex in the Brazilian specimen are very slightly less flared laterally. However, the posterior margin of the hypandrium is slightly bilobed with a medial carina ventrally, just as in the holotype male. Two of the female paratypes from Costa Rica show evidence of darkening on the haltere, but not nearly as boldly as in the Brazilian male. It is possible that the Brazilian specimen represents a third species, but the differences are minor enough that its status cannot be determined with certainty until additional material is available for study.

\section{Acknowledgments}

I am very grateful to Manuel Zumbado (INBio), David Grimaldi (AMNH), and Stephen Gaimari (CDFA) for expediting loans of material in their care. Taina Litwak prepared the drawings of male terminalia. Charyn Micheli took all of the photographic images and prepared all of the final plates. Owen Lonsdale (Smithsonian Institution), Steven Lingafelter and Allen Norrbom (Systematic Entomology Laboratory, USDA) provided reviews of the manuscript.

\section{References}

Brammer, C.A. \& von Dohlen, C.D. (2007) Evolutionary history of Stratiomyidae (Insecta: Diptera): The molecular phylogeny of a diverse family of flies. Molecular Phylogenetics and Evolution, 43, 660-673.

Curran, C.H. (1934) The Diptera of Kartabo, Bartica District, British Guiana, with descriptions of new species from other British Guiana localities. Bulletin of the American Museum of Natural History, 66, 287-532.

Kertész, K. (1908) Vorarbeiten zu einer Monographie der Notacanthen. I-XI. Annales Historico-Naturales Musei Nationalis Hungarici, 6, 321-374.

Kertész, K. (1923) Vorarbeiten zu einer Monographie der Notacanthen. XLV-L. Annales Historico-Naturales Musei Nationalis Hungarici, 20, 85-129.

McAlpine, J.F. (1981) Morphology and terminology-adults. In: McAlpine, J.F., Peterson, B.V., Shewell, G.E., Teskey, H.J., Vockeroth, J.R., \& Wood, D.M. (coordinators), Manual of Nearctic Diptera, Vol. 1. Research Branch, Agriculture Canada Monograph, 27, Ottawa, pp. 9-63.

Woodley, N.E. (2001) A world catalog of Stratiomyidae (Insecta: Diptera). Myia, 11, (8) + 1-475. 